\title{
Monitoring soil coverage and yield of cowpea furrow irrigated with saline water ${ }^{1}$
}

\author{
Monitoramento da cobertura do solo e produtividade do feijão-de-corda irrigado por \\ sulcos com água salina
}

\author{
Antonia Leila Rocha Neves ${ }^{2 *}$, Claudivan Feitosa de Lacerda ${ }^{3}$, Adunias dos Santos Teixeira ${ }^{4}$, Carlos Alexandre \\ Gomes Costa ${ }^{5}$ e Hans Raj Gheyi ${ }^{6}$
}

\begin{abstract}
Cowpea crop is of great importance for northeast Brazil. The objective of this work was to evaluate the application of saline water in different developing stages on plant growth and changes in soil characteristics, measured by soil coverage, and on yield of cowpea plants. The experiment was conducted under field conditions, during the dry season in a completely randomized block design with five treatments and five replications. Each experimental unit consisted of 4 lines of plants with $5.0 \mathrm{~m}$ long. The treatments evaluated were: 1 . irrigation with groundwater with electrical conductivity ( $\mathrm{ECW}$ ) of $0.8 \mathrm{dS} \mathrm{m}^{-1}$ during the whole crop cycle; 2 . saline water $\left(5.0 \mathrm{dS} \mathrm{m}^{-1}\right)$ during the whole crop cycle; 3,4 and 5 . saline water $\left(5.0 \mathrm{dS} \mathrm{m}^{-1}\right)$ up to $22^{\text {nd }}$, during $23^{\text {rd }}$ to $42^{\text {nd }}$ and from the $43^{\text {rd }}$ to $62^{\text {nd }}$ days after sowing, respectively, and groundwater in the remaining period. Soil coverage was evaluated by digital images using the software ENVI for image processing and classification. It was found that the continuous use of saline water inhibits plant growth, while irrigation with saline water during germination and initial growth stages caused retardation in plant development, but in this last case a recovery was observed in the final part of the experimental period. For treatments 2 and 3 , a reduction was verified in the number of pods and in seed production, as compared to other treatments. Irrigation with saline water during 23 to 42 and 43 to 62 days after sowing did not affect reproductive and vegetative growth, but the saline water application in the pre-flowering (treatment 4) caused anticipation of the reproductive cycle.
\end{abstract}

Key words - Vigna unguiculata. Image classification. Salinity of the water. Salt tolerance.

Resumo - Feijão-de-corda é uma cultura de grande importância socioeconômica no Nordeste brasileiro. O objetivo deste trabalho foi avaliar a aplicação de água salina em diferentes estádios de desenvolvimento e no rendimento do feijão-de-corda (caupi) e alterações em características do solo. O experimento foi conduzido no campo, durante a estação seca em um delineamento em blocos casualizados com cinco tratamentos e cinco repetições. Cada unidade experimental constou de 4 linhas de plantio com $5,0 \mathrm{~m}$ de comprimento. Os tratamentos avaliados foram: 1. irrigação com água subterrânea com a condutividade elétrica (CEa) de $0,8 \mathrm{dS} \mathrm{m}^{-1}$ durante todo o ciclo da cultura; 2 . água salina $\left(5,0 \mathrm{dS} \mathrm{m}^{-1}\right)$ durante todo o ciclo; $3,4 \mathrm{e} 5$. irrigação com água salina até 22 , de 23 a 42 e de 43 a 62 dias após o plantio, respectivamente, e no resto do ciclo irrigada com água subterrânea. A cobertura do solo foi avaliada por imagens digitais e utilizou-se o software ENVI para processamento e classificação. Verificou-se que o uso contínuo de água salina inibiu o crescimento das plantas, enquanto a irrigação com água salina durante a germinação e o crescimento inicial retardou o desenvolvimento, mas no último caso, a recuperação foi observada na parte final do período experimental. Para os tratamentos 2 e 3, foi verificada redução no número de vagens e na produção de sementes, em comparação com outros tratamentos. A irrigação com água salina durante 20 a 40 e 40 a 60 dias após a germinação não afetou o crescimento vegetativo e reprodutivo, sendo que a aplicação de água salina na pré-floração (tratamento 4) causou antecipação do ciclo reprodutivo.

Palavras-chave - Vigna unguiculata. Classificação por imagem. Salinização da água. Tolerância à salinidade.

\footnotetext{
* Corresponding author

Received 04/05/2009; accepted 12/02/2010

Projeto de pesquisa financiado pelo CT-Hidro/CNPq; Parte da dissertação do primeiro autor apresentada ao Departamento de Engenharia Agrícola, CCA/UFC, Ceará

${ }_{2}^{2}$ Programa de Pós-Graduação da Universidade Federal do Ceará, CCA/UFC, Fortaleza-CE, Brasil, 60021-970, leilaneves7@hotmail.com

${ }^{3}$ Departamento de Engenharia Agrícola, CCA/UFC, Instituto Nacional de Ciência e Tecnologia em Salinidade (INCTSal/CNPq), Fortaleza-CE, Brasil, cfeitosa@ufc.br

${ }^{4}$ Departamento de Engenharia Agrícola, CCA/UFC, Instituto Nacional de Ciência e Tecnologia em Salinidade (INCTSal/CNPq), Fortaleza-CE, Brasil, adunias@ufc.br

${ }^{5}$ Programa de Pós-Graduação da Universidade Federal do Ceará, CCA/UFC, Fortaleza-CE, Brasil, alexandreagronomia@yahoo.com.br

${ }^{6}$ Departamento de Engenharia Agrícola, UFCG, Campina Grande-PB, Brasil, Instituto Nacional de Ciência e Tecnologia em Salinidade (INCTSal/

CNPq), hans@deag.ufcg.edu.br
} 


\section{Introduction}

The use of irrigation has contributed significantly to increased agricultural production, especially in the semi arid regions, where the total rainfall limits the plant yield (RHOADES et al., 2000). However, there are some areas, including the Northeast of Brazil, where availability of freshwater resources increases or decreases according to rainfall changes, and there is competition for freshwater among different water-users, causing a decreased allocation of freshwater to agriculture (MURTAZA et al., 2006). In addition, in these regions, existence of sources of water containing high amounts of soluble salts is common, causing problems in plant growth and crop yield.

The use of saline water in agriculture depends on some factors, such as salt tolerance of crops, physical properties of soil, drainage conditions, and the total rainfall of the region. The evaluation of these factors allows the formulation of long term strategies, which contribute to obtain economical harvests without soil degradation. Among these strategies, one can find: cultivation of salt tolerant species, the use of alternative soil management techniques, the crop rotation, the use of blended water, the application of soil amendments, and the use of saline water during salt tolerant growth stages (GLENN et al., 1998; MALASH et al., 2005; MURTAZA et al., 2006; NEVES et al., 2008; SHARMA; RAO, 1998).

The sensitivity of crops to soil salinity often changes from one growth stage to the next (MAAS; POSS, 1989), and some efforts have been made with different crops to develop appropriate management practices for irrigation with saline water, with respect to the timing of its application, to reduce yield losses and soil salinization (BOTIA et al., 2005). These studies aim at determining the sensitivities of the crop at different growth stages, which is one of the major issues in the utilization of saline water for crop production. With the identification of salt-sensitive or salt-tolerant growth stages, management options may be developed to ameliorate yield reduction under salt stress, while reducing the consumption of good quality water (CHARTZOULAKIS; KLAPAKI, 2000; ZENG et al., 2001).

Cowpea [Vigna unguiculata (L.) Walp.] is an important crop cultivated in different regions of the world, being an important source of vegetal protein for human consumption in semi arid regions. This crop is extensively cultivated in the Northeast of Brazil, and presents great social and economical importance, especially for the poorest portion of its population (CARDOSO et al., 2005). Cowpea has been cultivated under both irrigated and non-irrigated regimes, and it is considered a moderately sensitive crop to salinity (MAAS; GRATTAN 1999), with a higher tolerance than corn, but lower than wheat, barley, sugar beet, and cotton (AMADOR et al., 2006).

Although there are many studies related to salt tolerance of cowpea under greenhouse conditions (COSTA et al., 2003; DANTAS et al., 2002; MAAS; POSS, 1989), there is little information about its tolerance in different growth stages, especially under field conditions. Therefore, in this study the effect of the application of saline water at different stages of crop on plant growth and yield was evaluated, with the objective to identify the response of cowpea at different development stages to application of saline water, as well as the impacts of these treatments on the soil properties.

\section{Material e methods}

The experiment was carried out during the last three months of the dry season, between October and December, 2006, in an area of Red Yellow Argisol (chemical and physical characteristics were previously described by Assis Junior et al. (2007), in Fortaleza ( $3^{\circ} 45^{\prime} \mathrm{S}$; $\left.38^{\circ} 33^{\prime} \mathrm{W}\right)$, Ceará, Brazil where cowpea [Vigna unguiculata (L) Walp.] cv. Epace 10 was sown. The weather conditions during the experimental period (October to December, 2006) and during rainy season (January to April, 2007) after cultivation of cowpea are characterized in Table 1.

Table 1 - Values of the meteorological data obtained during dry season (along cowpea cultivation) and during rainy season

\begin{tabular}{|c|c|c|c|c|c|c|}
\hline Months & $\mathrm{T}\left({ }^{\circ} \mathrm{C}\right)$ & RU (\%) & $\mathrm{v}\left(\mathrm{m} \mathrm{s}^{-1}\right)$ & Insolation (hours) & Rainfall (mm) & $\mathrm{ETP}(\mathrm{mm})$ \\
\hline Out/2006 & 27.7 & 68 & 4.5 & 327 & 3.2 & 196.3 \\
\hline Nov/2006 & 27.5 & 70 & 4.3 & 297 & 2.7 & 183.4 \\
\hline Dec/2006 & 28.1 & 72 & 3.7 & 341 & 11.7 & 164.7 \\
\hline $\operatorname{Jan} / 2007$ & 28.3 & 73 & 3.7 & 259 & 36.5 & 159.5 \\
\hline $\mathrm{Feb} / 2007$ & 27.1 & 81 & 2.8 & 148 & 279.8 & 83.2 \\
\hline Mar/2007 & 27.2 & 80 & 2.7 & 179 & 340.0 & 115.7 \\
\hline April/2007 & 27.4 & 79 & 2.5 & 168 & 236.9 & 113.7 \\
\hline
\end{tabular}

$\mathrm{T}$ - mean temperature, RU - relative humidity, $\mathrm{v}$ - wind velocity, ETP - potential evapotranspiration 
A completely randomized block design, with five replications, was adopted. Each experimental unit consisted of four lines of plants, each $5.0 \mathrm{~m}$ long. The distance between lines and plants were 0.8 and $0.3 \mathrm{~m}$, respectively, with two plants per hole.

The plants were subjected to the following treatments of irrigation: 1). Irrigation with groundwater of $0.8 \mathrm{dS} \mathrm{m} \mathrm{m}^{-1}$ electrical conductivity (ECw) during the whole crop cycle; 2). Irrigation with saline water $\left(\mathrm{ECw}=5.0 \mathrm{dS} \mathrm{m}^{-1}\right)$ during the whole crop cycle, starting after germination; the value of $5.0 \mathrm{dS} \mathrm{m}^{-1}$ was chosen on the basis of study of Dantas et al. (2002) and Assis Júnior et al. (2007). This concentration of salts in irrigation water causes nearly $40 \%$ reduction in yield and is superior than the threshold limit for the crop which according to Ayers e Westcot (1999), is of $3.3 \mathrm{dS} \mathrm{m}^{-1}$; 3). Irrigation with saline water $\left(\mathrm{ECw}=5.0 \mathrm{dS} \mathrm{m}^{-1}\right)$ from sowing until $22^{\text {nd }}$ day after seedling emergence (germination and initial growth) and groundwater in remaining stages of the crop cycle; 4). Irrigation with saline water $\left(\mathrm{ECW}=5.0 \mathrm{dS} \mathrm{m}^{-1}\right)$ from $23^{\text {rd }}$ to $42^{\text {nd }}$ day after germination (intense growth and pre-flowering), and irrigation with groundwater for the remaining growth stages and 5). Irrigation with groundwater $\left(\mathrm{ECw}=0.8 \mathrm{dS} \mathrm{m}^{-1}\right)$ from sowing to the $43^{\text {rd }}$ day after germination and irrigation with saline water $\left(\mathrm{ECw}=5.0 \mathrm{dS} \mathrm{m}^{-1}\right)$ during flowering and podfilling stages. For the preparation of the saline waters, $\mathrm{NaCl}$, $\mathrm{CaCl}_{2} \cdot 2 \mathrm{H}_{2} \mathrm{O}$ and $\mathrm{MgCl}_{2} \cdot 6 \mathrm{H}_{2} \mathrm{O}$ were used maintaining the equivalent ratio 7:2:1 for $\mathrm{Na}: \mathrm{Ca}: \mathrm{Mg}$ (proportion commonly observed in waters of northeast Brazil), and following the $\mathrm{ECw}$ - salt concentration relationship ( mmol $\left._{\mathrm{c}} \mathrm{L}^{-1}=\mathrm{CE} \times 10\right)$ reported by Rhoades et al. (2000). The main characteristics of the groundwater and saline water used in irrigation are presented in Table 2.

Irrigation schedule adopted was according to crop water requirements based on reference evapotranspiration, ETo (estimated from a Class A pan according to Doorenbos e Pruit (1997) and the values of the crop coefficients $\left(\mathrm{K}_{\mathrm{c}}\right)$ according to the growth stage, as follows: 0.70 (0 to 10 days after sowing, DAS), 0.81 (11 to 30 DAS), 1.12
(31 to 53 DAS) and 0.77 (54 to 60 DAS), following recommendation presented by Souza et al. (2005). An additional $15 \%$ leaching fraction was added to the net water requirement to prevent excessive salt accumulation. A dead-end leveled furrow irrigation system was used for the experiment. The total water applied during the irrigation cycle was $352 \mathrm{~mm}$ in all treatments.

The fertilization followed the recommendation of Fernandes (1993), and consisted of applying $1.1 \mathrm{~g}$ of urea, $8.0 \mathrm{~g}$ of simple superphosphate, and $1.5 \mathrm{~g}$ of potassium chloride for each plant. During the crop development, two manual weedings were carried out and the application of agricultural defensives was performed in accordance with the necessities.

Plant canopy coverage was assessed by digital images taken at weekly intervals from a $2 \mathrm{~m}$ high platform and using a 5.1 megapixels digital camera and an 80 by $80 \mathrm{~cm}$ grid as backgound. In order to avoid any distortion due to shade, images were taken at noon time. The raw images were edited using Adobe Photoshop software to produce a net covered area of $6400 \mathrm{~cm}^{2}$ (Figure 1). Software ENVI 4.3 RSI was used to quantify the area of crop coverage applying the supervised classification algoritm known as Maximum LikelihoodMaxver. It considers the balance of distances between means of the digital levels of the classes and pixel, using statistical parameters, considering the distribution of normal probability for each class.

At the end of the crop cycle, the following parameters were measured: dry mass of vegetative (stems, petioles and leaf blades) and reproductive (pods and seeds) plant parts, number of pods per plant, number of seeds per pod, size of the pod, and dry biomass of 1000 seeds. Dry biomass partitioning between vegetative and reproductive parts was also evaluated.

Soil samples from three layers $(0-0.3 ; 0.3-0.6$ and 0.6-0.9 m) were collected during the dry season (before and after cowpea cultivation) and after the rainy season, to determine electrical conductivity in 1:1 soil water extract

Table 2 - Characteristics of groundwater (from well) and saline water used in irrigation

\begin{tabular}{cccc}
\hline Characteristics & Unit & Groundwater & Saline water \\
\hline $\mathrm{EC}$ & $\left(\mathrm{dS} \mathrm{m}^{-1}\right)$ & 0.8 & 5.0 \\
$\mathrm{pH}$ & & 7.1 & 7.1 \\
$\mathrm{Ca}^{2+}$ & $\mathrm{mmol}_{\mathrm{c}} \mathrm{L}^{-1}$ & 1.0 & 10.0 \\
$\mathrm{Mg}^{2+}$ & $\mathrm{mmol}_{\mathrm{c}} \mathrm{L}^{-1}$ & 1.0 & 5.0 \\
$\mathrm{Na}^{+}$ & $\mathrm{mmol}_{\mathrm{c}} \mathrm{L}^{-1}$ & 3.9 & 35.0 \\
$\mathrm{HCO}_{3-}$ & $\mathrm{mmol}_{\mathrm{c}} \mathrm{L}^{-1}$ & 2.8 & 2.8 \\
$\mathrm{Cl}^{-}$ & $\mathrm{mmol}_{\mathrm{c}} \mathrm{L}^{-1}$ & 3.6 & 65.0 \\
$\mathrm{SAR}$ & $\left(\mathrm{mmol} \mathrm{L}^{-1}\right)^{1 / 2}$ & 3.9 & 12.8 \\
\hline
\end{tabular}



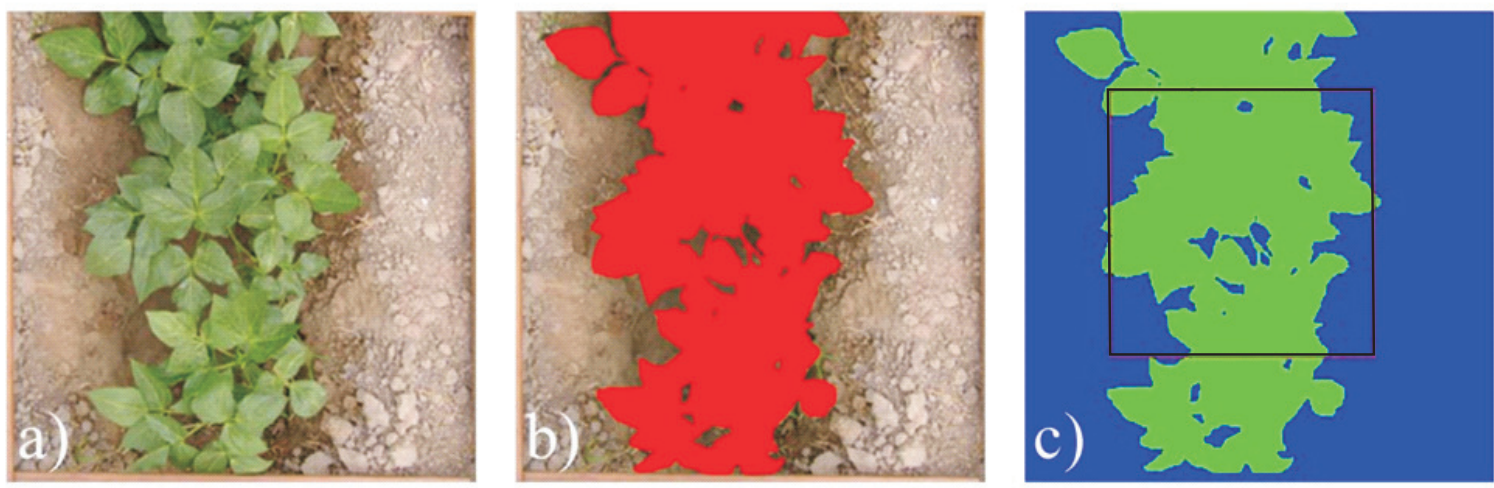

Figure 1 - (A) image obtained in the field; (B) edited image in the computer; (C) classified image by ENVI method

$\left(\mathrm{EC}_{1: 1}\right)$ and exchangeable sodium percentage (ESP), according to methods recommended in Silva (1999).

The data were subjected to analysis of variance, and the means were compared by Tukey's test at 0.05 level of probability.

\section{Results and discussion}

\section{Salt accumulation in soil}

Soil profile salinity $\left(\mathrm{EC}_{1: 1}\right)$ and sodicity (ESP) at the start of the experiment (October, 2006) ranged from 0.29 to $0.60 \mathrm{dS} \mathrm{m}^{-1}$ and from 3 to $6 \%$, respectively
(Table 3). The irrigation with combination of groundwater and saline water, during the last three months of the dry season, caused an increase in electrical conductivity and exchangeable sodium levels in the soil profile (Table 3) due to accumulation of salts. However, the response to the treatment varied according to the duration of the exposure to saline water at a given growth stage and was dependant upon the soil layer. The continuous use of saline water (treatment 2) caused larger increases in $\mathrm{EC}_{1: 1}$ and in ESP for the three layers studied, although higher values were observed for the 0.3 to $0.6 \mathrm{~m}$ layer. When saline water was used only during germination and initial growth stages (treatment 3), higher values of $\mathrm{EC}_{1 \cdot 1}$ and $\mathrm{ESP}$ were observed in the layers between 0.3 and $0.9 \mathrm{~m}$, and the values in the superficial layer were quite similar to those

Table 3 - Values of electrical conductivity obtained in 1:1 soil/water extracts $\left(\mathrm{EC}_{1: 1}\right)$ and of exchangeable sodium percentage (ESP) at different soil depths

\begin{tabular}{|c|c|c|c|c|c|c|}
\hline \multirow{2}{*}{ Treatment } & \multicolumn{3}{|c|}{$\mathrm{CE}_{1: 1}\left(\mathrm{dS} \mathrm{m}^{-1}\right)$} & \multicolumn{3}{|c|}{ ESP $(\%)$} \\
\hline & $0-0.3 \mathrm{~m}$ & $0.3-0.6 \mathrm{~m}$ & $0.6-0.9 \mathrm{~m}$ & $0-0.3 \mathrm{~m}$ & $0.3-0.6 \mathrm{~m}$ & $0.6-0.9 \mathrm{~m}$ \\
\hline & \multicolumn{6}{|c|}{ September of 2006 (before sowing of cowpea ) } \\
\hline & 0.29 & 0.36 & 0.60 & 3 & 6 & 9 \\
\hline & \multicolumn{6}{|c|}{ January of 2007 (after harvest of cowpea) } \\
\hline $\mathrm{T} 1$ & 0.43 & 0.58 & 0.30 & 12 & 12 & 11 \\
\hline $\mathrm{T} 2$ & 1.15 & 1.39 & 1.15 & 19 & 23 & 19 \\
\hline $\mathrm{T} 3$ & 0.57 & 0.99 & 0.94 & 13 & 15 & 16 \\
\hline $\mathrm{T} 4$ & 0.66 & 1.17 & 0.74 & 13 & 15 & 15 \\
\hline \multirow[t]{2}{*}{$\mathrm{T} 5$} & 0.91 & 0.72 & 0.42 & 15 & 11 & 10 \\
\hline & \multicolumn{6}{|c|}{ April of 2007 (after rainy season) } \\
\hline T1 & 0.17 & 0.16 & 0.24 & 5 & 9 & 10 \\
\hline $\mathrm{T} 2$ & 0.14 & 0.17 & 0.28 & 7 & 11 & 9 \\
\hline $\mathrm{T} 3$ & 0.16 & 0.13 & 0.15 & 7 & 7 & 9 \\
\hline $\mathrm{T} 4$ & 0.19 & 0.15 & 0.17 & 3 & 8 & 8 \\
\hline T5 & 0.10 & 0.11 & 0.17 & 6 & 8 & 9 \\
\hline
\end{tabular}


observed in treatment 1 (groundwater). This could be due to the use of groundwater during the remaining stages of the crop cycle, causing salts to leach from the surface layer. On the other hand, application of the saline water at the end of the crop cycle (treatment 5) caused higher salt accumulation in the superficial layer, suggesting that the time was insufficient to promote salt distribution/ leaching in the soil profile. Soil analysis after the rainy season revealed a decrease in soil salinity and sodicity in all treatments probably because of leaching caused by rainwater during the months of January to April. However the decrease in the electrical conductivity was more evident than for exchangeable sodium because of solubility of accumulated salts in water.

\section{Soil coverage}

Allen et al. (1998) classified crop coefficients on the basis of development stages (initial stage - up to $10 \%$ of soil coverage; stage of development of the crop - approximately $70-80 \%$ of soil coverage; intermediate stage - total soil coverage until the beginning of the maturation; and final stage - beginning of the maturation until total senescence). Table 4 presents the evolution of the cowpea cv. EPACE 10 with $10 \%$ and $80 \%$ of soil covering submitted to irrigation with saline water in different stages of the cycle. Saline water application during the whole cycle reduced soil cover (Figure 2), and the plants under this treatment 2 did not fill $80 \%$ of the crop spacing (Table 4). The plants irrigated with saline water since sowing up to $20^{\text {th }}$ DAS (treatment 3 ) showed a reduction in the growth rate, and did not differ from plants of treatment 2 , in terms of soil coverage, until about 45 DAS. The plants under treatment 3, however, showed an intensive growth up to $45 \mathrm{DAS}$, and reached $80 \%$ of the soil coverage 57 DAS (Table 4 ), similar values were observed in other treatments. On the other hand, the plants of treatments 1 (irrigated with groundwater), 4 and 5 , showed higher growth along the cycle in relation to the plants of the treatments 2 and 3 , indicating that saline water application before flowering and during the flowering and pod-filling stages did not affect vegetative growth of the

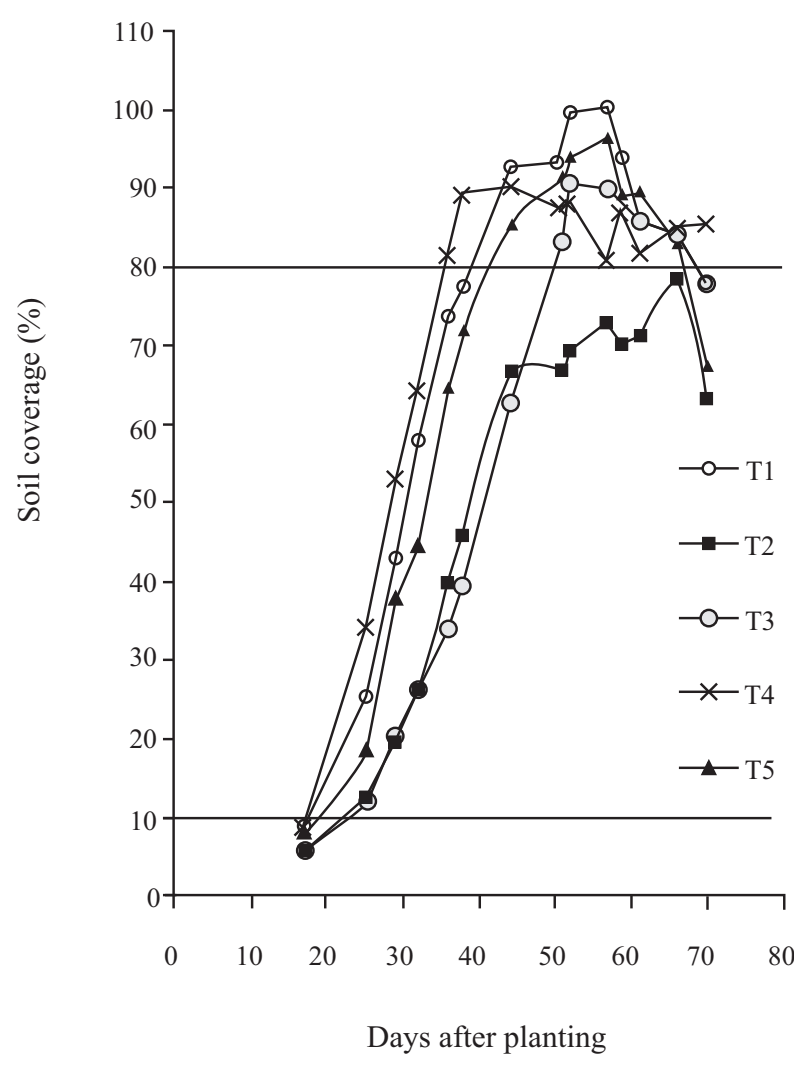

Figure 2-Evolution of the soil coverage by cowpea plants irrigated with saline water at different stages of plant development

crop. The plants of treatments 1 and 4 reached $80 \%$ of soil cover by the $40^{\text {th }}$ day after germination, but the plants of treatment 4 showed a tendency to stabilize after this period, suggesting an acceleration of plant senescence.

\section{Dry biomass production}

Continuous saline water application reduced the production of dry biomass of shoot, in relation to the plants irrigated with groundwater, and the reductions reached up to 40 and $46 \%$, respectively, for stems plus leaves and pods (Figure 3). Observed reductions may be due to osmotic, toxic and nutritional effects related

Table 4 - Limit values in days after sowing for changes in growth stages, according to Allen et al. (1998)

\begin{tabular}{lcc}
\hline \multicolumn{1}{c}{ Treatment } & \multicolumn{2}{c}{ Soil coverage } \\
\cline { 2 - 3 } & $10 \%$ & $80 \%$ \\
\hline T1. Well water & $19-20$ & $39-40$ \\
T2. Saline water during the complete crop cycle & $22-23$ & Did not reach \\
T3. Saline water during seedling germination and initial growth & $23-24$ & $56-57$ \\
T4. Saline water during the stage of intense growth and pre-flowering & $16-17$ & $39-40$ \\
T5. Saline water during flowering and fruit development & $20-21$ & $43-44$ \\
\hline
\end{tabular}


to salt accumulation in the root zone (Table 3) (due to $\mathrm{NaCl}$ principally), which might have affected carbon assimilation, inhibiting leaf expansion and enhancing leaf senescence, thereby reducing the area used for photosynthetic process and photosynthate production (LACERDA et al., 2006; MUNNS, 2002; WILSON et al., 2006). The plants irrigated with saline water during the germination and initial growth stages showed a $33 \%$ reduction in the reproductive growth. However, vegetative growth (leaves plus stems) was not affected, since a recovery in the vegetative development of the plant was observed along the crop cycle, as demonstrated in the measurement of the soil cover (Figure 2), and this effect could be related to reduction in salt accumulation in the root zone (Table 3). These results indicate that the salinity applied in the initial crop stage delayed plant development. This effect was observed in another study with this species during the seedling phase (SOUSA et al., 2003). In addition, alteration in the development pattern of the crop and in photosynthate partitioning was observed, causing reduction in the pod production in detriment of the vegetative growth (Table 5). Salt-induced changes in morphophysiology of cowpea plants have also been observed in other studies (LACERDA et al., 2006).

The saline water application in the periods of intense growth and in the flowering and pod-filling stages did not affect the vegetative growth and pod production per plant (Figure 3), which indicates that germination and seedling establishment stages are more sensitive to salt accumulation in the root zone (AMADOR et al., 2006). Maas e Poss (1989) observed reduction in the vegetative growth in cowpea under

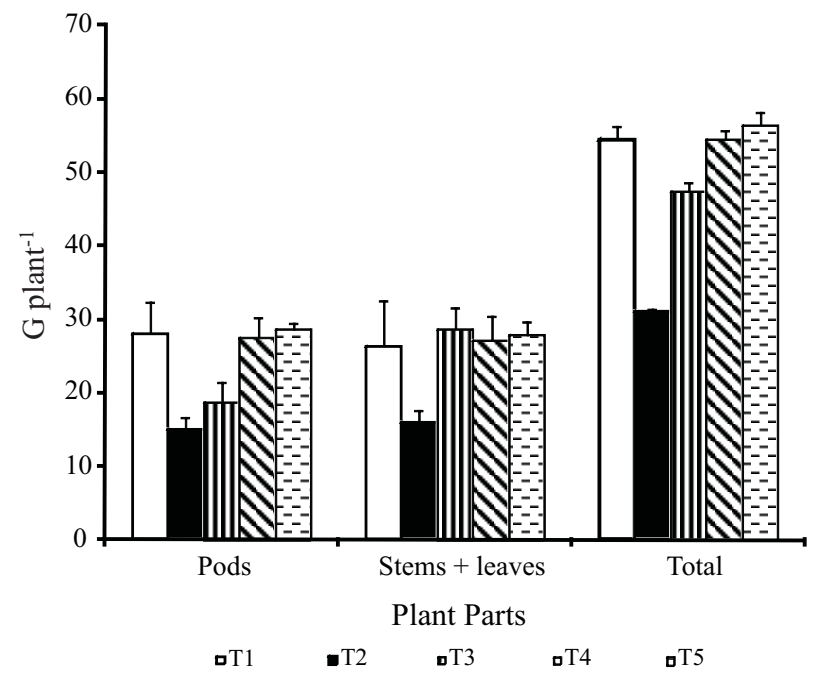

Figure 3 - Dry biomass of reproductive (pods) and vegetative parts (stems plus leaves) of cowpea plants irrigated with saline water at different stages of plant development. Bars represent SE $(n=5)$
Table 5 - Dry biomass partitioning in cowpea plants irrigated with saline water at different stages of plant development

\begin{tabular}{ccc}
\hline Treatments & Vegetative Parts & Reproductive parts \\
\hline T1 & $47.2 \mathrm{~b}$ & $52.8 \mathrm{a}$ \\
T2 & $51.0 \mathrm{~b}$ & $49.0 \mathrm{a}$ \\
T3 & $60.0 \mathrm{a}$ & $40.0 \mathrm{~b}$ \\
T4 & $49.0 \mathrm{~b}$ & $51.0 \mathrm{a}$ \\
T5 & $49.5 \mathrm{~b}$ & $50.5 \mathrm{a}$ \\
\hline
\end{tabular}

${ }^{1}$ Means followed by the same letter in columns do not differ significantly (Tukey's test, $P \leq 0.05$ ); $n=5$

greenhouse condition, both when saline water was applied during the growth and during flowering and pod-filling stages, but the highest reduction was verified when the crop was irrigated with saline water during the initial stage of plant growth. According to Maas (1993), most crops show higher sensitivity to salt injury during seedling emergence and early juvenile development. Once established, plants generally become increasingly tolerant until the final stage. On the other hand, it was observed that the saline water application in the pre-flowering stage caused acceleration in the reproductive development, while the saline water application in the initial growth stage caused retardation in the pod filling. On the $58^{\text {th }}$ day after germination, when the first harvest was carried out, it was verified that the plants of treatment 4 had, on average, about 3 mature pods, while practically no mature pods were observed in the plants of treatment 3 (Figure 4). It was also observed that the

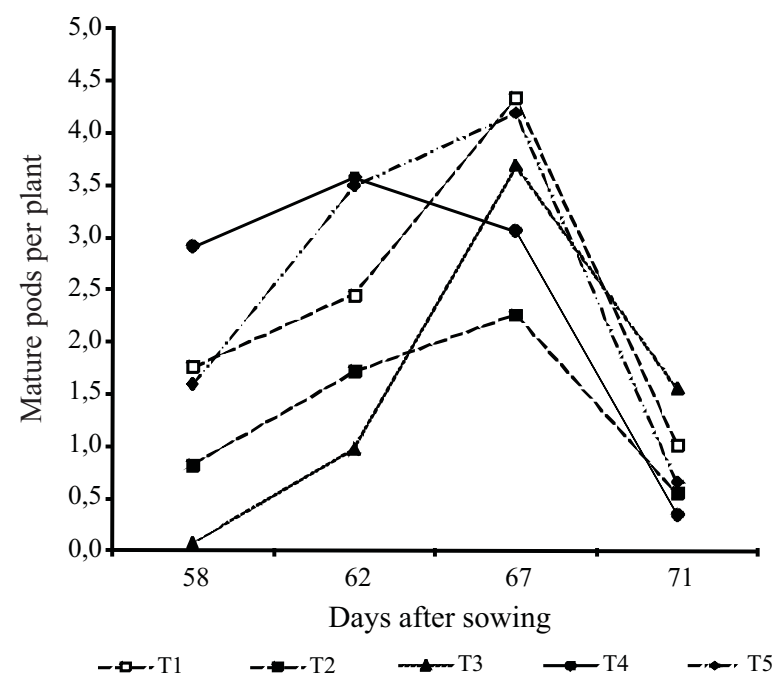

Figure 4 - Number of mature pods per plant, along the harvest period, of cowpea plants irrigated with saline water at different stages of plant development 
Table 6 - Number of pods per plant (NP), number of seeds per pod (NSP), size of the pod (SP), dry biomass of 1000 seeds (DM1000), and total dry biomass of seeds per plant (DMS) of cowpea plants irrigated with saline water at different stages of plant development

\begin{tabular}{cccccc}
\hline Treatments & NP & NSP & SP $(\mathrm{cm})$ & DM1000 $(\mathrm{g})$ & ${\text { DMS }\left(\mathrm{g} \mathrm{plant}^{-1}\right)}^{\text {T }}$ \\
\hline T1 & $8.7 \mathrm{a}$ & $14.3 \mathrm{ab}$ & $19.7 \mathrm{a}$ & $184.1 \mathrm{a}$ & $22.4 \mathrm{a}$ \\
T2 & $5.1 \mathrm{~b}$ & $12.8 \mathrm{~b}$ & $18.8 \mathrm{a}$ & $198.3 \mathrm{a}$ & $11.8 \mathrm{~b}$ \\
T3 & $5.9 \mathrm{~b}$ & $14.3 \mathrm{ab}$ & $19.2 \mathrm{a}$ & $198.7 \mathrm{a}$ & $14.9 \mathrm{~b}$ \\
T4 & $9.3 \mathrm{a}$ & $14.2 \mathrm{ab}$ & $19.6 \mathrm{a}$ & $203.9 \mathrm{a}$ & $21.9 \mathrm{a}$ \\
T5 & $9.2 \mathrm{a}$ & $14.7 \mathrm{a}$ & $20.1 \mathrm{a}$ & $198.8 \mathrm{a}$ & $22.5 \mathrm{a}$ \\
\hline
\end{tabular}

${ }^{1}$ Means followed by the same letter in columns do not differ significantly (Tukey's test, $P \leq 0.05$ ); $n=5$

maximum production of the treatment 4 occurred at the $62^{\text {nd }}$ day after the germination, while in the other treatments this peak only occurred at the $67^{\text {th }}$ days.

The seed production of cowpea results from the number of pods (NP) per unit area, the numbers of seeds per pod (NSP) and from the weight of 1000 seeds (DM1000) (CARDOSO et al., 2005). In the present work it was verified that the continuous application of saline water, as well as application during germination and initial growth stages, reduced dry biomass of pods and seeds, but no reduction in the pod size and in the mean weight of the seeds was observed (Table 6), similar results was also obtained by Maas e Poss (1989). However, a reduction in the number of pods per plant and in the number of seeds per pod were verified, demonstrating that the salinity affected the emission of reproductive branches, this being an important component for the reduction in the cowpea yield under salt stress conditions. These results are partially in accordance to those obtained by Maas e Poss (1989) under greenhouse conditions, which showed that cowpea is most sensitive to salinity during early vegetative growth but exhibits higher tolerance during flowering and pod-filling stages.

\section{Conclusions}

1. Saline water application during whole cycle increased salinity in the soil profile and reduced the growth and yield of cowpea.

2. The saline water application during germination and initial growth stages caused retardation in plant development and reduced the final crop yield mainly due to reduction in number of pods per plant.

3. The saline water use in the periods from 23 to 42 and 43 to 62 days after sowing did not affect the cowpea growth and yield, however the application in former case caused an acceleration in the formation and filling of pods.
4. Use of saline water during 43 to 62 days after sowing permit to obtain economic harvests without soil degradation reducing the consumption of good quality water.

5. No appreciable increase in soil salinity due to application of saline water was observed after the rainy season.

\section{Acknowledgments}

The authors are grateful to "Fundo Setorial CT-HIDRO" and to "Conselho Nacional de Desenvolvimento Científico e Tecnológico - CNPq", Brazil, for financial support.

\section{Reference}

ALLEN, R. G. et al. Crop evapotranspiration: guidelines for computing crop water requirements. Rome: FAO, 1998. 392 p. (Irrigation and Drainage Paper, 56).

AMADOR, B. M. et al. Effect of $\mathrm{NaCl}$ salinity in the genotypic variation of cowpea (Vigna unguiculata) during early vegetative growth. Scientia Horticulturae,v. 108, n. 04, p. 423-431, 2006.

ASSIS JÚNIOR, J.O. et al. Produtividade do feijão-de-corda e acúmulo de sais no solo em função da fração de lixiviação e da salinidade da água de irrigação. Engenharia Agrícola, v.27, n.3 p.702-713, 2007.

BOTÍA, P. et al. Yield and fruit quality of two melon cultivars irrigated with saline water at different stages of development. European Journal of Agronomy, v. 23, n. 03, p. 243-253, 2005.

CARDOSO, J. M.; MELO, F. B.; LIMA, M. G. Ecofisiologia e Manejo de Plantio. In: FEIRE FILHO, F. R.; LIMA, J. A. A.; RIBEIRO, V. Q. Feijão caupi avanços tecnológicos. Brasilia: EMBRAPA, 2005. p. 213-225.

CHARTZOULAKIS, K.; KLAPAKI, G. Response of two greenhouse pepper hybrids to $\mathrm{NaCl}$ salinity during different growth stages. Scientia Horticulturae, v. 86, n. 03, p. $247-$ 260,2000 . 
COSTA, P. H. A. et al. Crescimento e níveis de solutos orgânicos e inorgânicos em cultivares de Vigna unguiculata submetidos à salinidade. Revista Brasileira de Botânica, v. 26, n. 03, p. 289-297, 2003.

DANTAS, J. P. et al. Avaliação de genótipos de caupi sob salinidade. Revista Brasileira de Engenharia Agrícola e Ambiental, v. 06, n. 03, p. 425-430, 2002

DOORENBOS, W. O.; PRUITT, W. O. Necessidades hídricas das culturas. Campina Grande: UFPB, 1997. 204 p.

FERNANDES, V. L. B. Recomendações de adubação e calagem para o estado do Ceará. Fortaleza: Universidade Federal do Ceará, 1993. 248 p.

GLENN, E. et al. Water use, productivity and forage quality of the halophyte Atriplex nummularia grown on saline waste water in a desert environment. Jourmal of Arid Environments, v. 38, n. 09, p. 45-62, 1998.

LACERDA, C. F. et al. Morpho-physiological responses of cowpea leaves to salt stress. Brazilian Journal of Plant Physiology, v. 18, n. 04, p. 455-465, 2006.

MAAS, E. V. Testing Crops for Salinity Tolerance. In: MARANVILLE, J.W. et al. (Ed.). Workshop on Adaptation of Plants to Soil Stresses INTSORMI. 1993, Nebraska. Proceedings... Lincoln: University of Nebraska, 1993. p. 234-247.

MAAS, E. V.; GRATTAN, S. R. Crop yields as affected by salinity. In: SKAGGS, R.W.; SCHHILFGAARD, J. Van. (Ed.) Agricultural drainage. Madison: ASA/CSSA/SSSA, 1999. p. 55-108.

MAAS, E. V.; POSS, J. A. Salt sensitive of cowpea at various growth stages. Irrigation Science, v. 10, n. 04, p. 313-320, 1989.

MALASH, N.; FLOWERS, T. J.; RAGAB, R. Effect of irrigation systems and water management practices using saline and non-saline water on tomato production. Agricultural Water Management, v. 78, n. 01-02, p. 25-38, 2005.

MUNNS, R. Comparative physiology of salt and water stress. Plant, Cell and Environment, v. 25, p. 239-250, 2002.

MURTAZA, G.; GHAFOOR. A.; QADIR, M. Irrigation and soil management strategies for using saline-sodic water in a cotton-wheat rotation. Agricultural Water Management, v. 81, n. 01-02, p. 98-114, 2006.

NEVES, A. L. R. et al. Tamanho e composição mineral de sementes de feijão-de-corda irrigado com água salina em diferentes estádios de desenvolvimento. Revista Ciência Agronômica, v. 39, n. 04, p. 569-574, 2008.

RHOADES, J. P.; ANDIAH, A.; MASHALI, A. M., Uso de águas salinas para produção agrícola. Campina Grande: UFPB, 2000. $117 \mathrm{p}$.

SHARMA, D. P.; RAO, K. V. G. K. Strategy for long term use of saline drainage water for irrigation in semi-arid regions. Soil \& Tillage Research, v. 48, n. 04, p. 287-295, 1998.

SILVA, F. C. Manual de análises químicas de solos, plantas e fertilizantes. Brasília: Embrapa, 1999. 370 p.

SOUSA, M. F. et al. Growth and protein pattern in cowpea seedlings subjected to salinity. Biologia Plantarum, v. 47, n. 03, p. 341-346, 2003

SOUZA, M. S. M.; BEZERRA, F. M. L.; TEÓFILO, E. M. Coeficientes de cultura do feijão caupi na região litorânea do Ceará. Irriga, v. 10, n. 03, p. 241-248, 2005.

WILSON, C. et al. Growth response of major USA cowpea cultivars. Plant Science, v. 170, n. 06, p. 1095-1101, 2006.

ZENG, L.; SHANNON, M. C.; LESCH, S. M. Timing of salinity stress affects rice growth and yield components. Agricultural Water Management, v. 48, n. 03, p. 191-206, 2001. 